\title{
Hungary: Political developments and data in 2018
}

\author{
RÉKA VÁRNAGY \\ Corvinus University of Budapest, Budapest, Hungary
}

\section{Introduction}

Despite it being a rather turbulent year with parliamentary elections on the calendar, 2018 did not turn around the major trends of the Hungarian political sphere: the governing Fidesz-Hungarian Civic Union-Christian-Democratic People's Party/Fidesz Magyar Polgári Szövetség-Kereszténydemokrata Néppárt (Fidesz-KDNP) maintained its political dominance while the opposition parties further disintegrated, the media landscape became even more centralized, and immigration and anti-European issues dominated the agenda scattered with corruption scandals and demonstrations.

\section{Election report}

\section{Parliamentary elections}

The first half of 2018 was dominated by a highly adversarial electoral campaign where the governing parties focused on anti-immigration messages and on the plans of George Soros. These messages were amplified by the government which financed public advertisements blurring the lines of campaign financing, and also by the public broadcaster that leaned towards the government in its coverage. In the meantime, opposition parties came short of an effective message to address the public. The left-wing parties competed for leadership of the opposition, while the leader of the radical right-wing Movement for a Better Hungary/Jobbik Magyarországért (Jobbik) Gábor Vona relentlessly pushed the party towards the centre-right with the support of the ex-Fidesz oligarch and media mogul, Lajos Simicska.

Owing to a lack of cooperation between them, opposition parties ran separate party lists, except for the MSZP-PM joint list, and consequently struggled with the need for cooperation in the single-member district (SMD) elections throughout the campaign. The Hungarian electoral system is a mixed system with 93 mandates distributed on party lists and 103 mandates in SMDs, thus the majoritarian element is critical to electoral success. Recognizing the lack of political commitment to coordinated candidate selection, there were many civil initiatives to identify the strongest opposition candidate in the SMDs and enable tactical voting, but without a clear message from parties these attempts were unsuccessful in changing the outcome of the elections. 
Table 1. Elections to Parliament (Magyar Országgyúlés) in Hungary in 2018

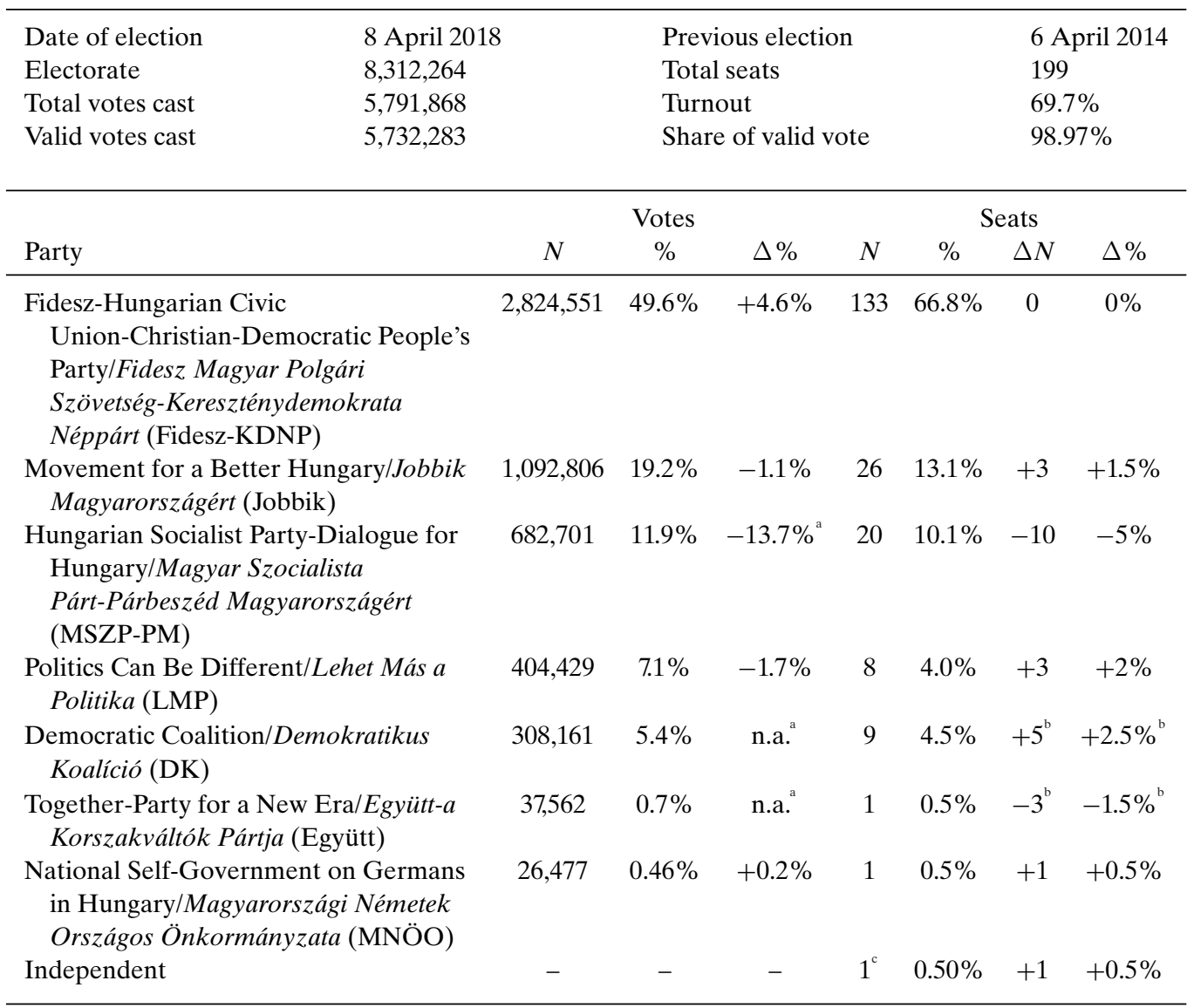

Notes: ${ }^{\mathrm{a}}$ At the previous election in 2014, the MSZP had a joint list with Együtt-DK-PM-MPL and together they reached $25.67 \%$ of party lists votes, while in 2018 the MSZP had a joint list with only PM. The comparison in list votes and seats is only presented for MSZP-PM.

${ }^{\mathrm{b}}$ The party did not have a PPG in the previous cycle; the change is compared with the number of MPs identifying with the given party.

${ }^{c}$ Preferential mandate won on ethnic minority party list.

Source: National Election Office, 2018.

Preceding the elections, a strong mobilization campaign took place on behalf of the opposition with the hope of reaching out to discontented voters. Indeed, turnout almost amounted to 70 per cent at the elections. Yet, the election results showed that in rural areas the government parties were more successful in their mobilization efforts, resulting in a landslide victory for the governing Fidesz-KDNP coalition that regained its qualified majority in Parliament. While according to the ODHIR (2018) report on the election, the process itself was free and well managed and voters could choose from various political alternatives, the media coverage was rather biased, hindering balanced access to political information. 


\section{Cabinet and Parliament report}

The Orbán IV government cannot be regarded as a simple continuation of the Orbán III government as many prominent politicians and ministers (such as Istán Lázár, Minister of the Prime Minister's Office, and Lajos Kósa, founder of Fidesz) left the political arena. With the weakened presence of the KDNP in the coalition, it is safe to predict that Viktor Orbán intends to lead a highly disciplined and centralized governmental structure.

Regarding the composition of Parliament, it is clear that the opposition does not have the potential to act as a check upon the government. The opposition is fractionalized, which is mirrored in its relatively high number of small parliamentary groups and the occurrence of opposition party splits which have resulted in an increase in the number of independent MPs who are even more powerless than factions.

Table 2. Cabinet composition of Orbán III in Hungary in 2018

\begin{tabular}{lllll}
\hline Duration of Cabinet & Inception & 6 June 2014 & Dissolution & 6 May 2018 \\
Period covered by table & From & 1 January 2018 & Until & 6 May 2018 \\
Type of Cabinet & Oversized coalition (OC) & & \\
& &
\end{tabular}

\begin{tabular}{|c|c|c|c|c|c|c|c|}
\hline \multirow[t]{2}{*}{ A. } & \multirow[t]{2}{*}{$\begin{array}{l}\text { Party/gender composition on } \\
1 \text { January } 2018\end{array}$} & \multicolumn{2}{|c|}{ Seats in Cabinet } & \multicolumn{2}{|c|}{$\begin{array}{l}\text { Seats held by } \\
\text { women }\end{array}$} & \multicolumn{2}{|c|}{ Seats in Parliament } \\
\hline & & $N$ & $\%$ & $N$ & $\%$ of party & $N$ & $\%$ \\
\hline & $\begin{array}{l}\text { Fidesz-Hungarian Civic Union/ } \\
\text { Fidesz Magyar Polgári } \\
\text { Szövetség (Fidesz) }\end{array}$ & 6 & $46.1 \%$ & 0 & $0 \%$ & 114 & $57.3 \%$ \\
\hline & $\begin{array}{l}\text { Christian-Democratic People's } \\
\text { Party/Kereszténydemokrata } \\
\text { Néppárt (KDNP) }\end{array}$ & 4 & $30.8 \%$ & 0 & $0 \%$ & 17 & $8.5 \%$ \\
\hline & No party affiliation & 3 & $23.1 \%$ & 0 & $0 \%$ & 0 & $0 \%$ \\
\hline & Totals & 13 & $100 \%$ & 0 & $0 \%$ & 131 & $65.8 \%$ \\
\hline
\end{tabular}

B. Composition of Orbán III Cabinet on 1 January 2018

See previous editions of the Political Data Yearbook for Hungary or http://politicaldatayearbook.com

C. Changes in composition of Orbán III Cabinet during 2018

Ministerial title Outgoing minister Outgoing date Incoming minister Comments

None

\begin{tabular}{lccccc}
\hline $\begin{array}{l}\text { D. Party/gender composition on } \\
\text { 6 May 2018 }\end{array}$ & Seats in Cabinet & \multicolumn{2}{c}{$\begin{array}{c}\text { Seats held by } \\
\text { women }\end{array}$} & \multicolumn{2}{c}{ Seats in Parliament } \\
& $N$ & $\%$ & $N$ & $\%$ of party & $N$ \\
\hline
\end{tabular}

No change during 2018

Source: Hungarian government, 2018 (www.kormany.hu). 
Table 3. Cabinet composition of Orbán IV in Hungary in 2018

\begin{tabular}{lllll}
\hline Duration of Cabinet & Inception & 18 May 2018 & $\begin{array}{l}\text { Dissolution } \\
\text { Period covered by table }\end{array}$ & $\begin{array}{l}\text { Still in office at the } \\
\text { end of the year }\end{array}$ \\
$\begin{array}{l}\text { Type of Cabinet } \\
\text { Oversized coalition (OC) }\end{array}$ & 18 May 2018 & Until & 31 December 2018
\end{tabular}

\begin{tabular}{|c|c|c|c|c|c|c|c|}
\hline \multirow[t]{2}{*}{ A. } & \multirow[t]{2}{*}{$\begin{array}{l}\text { Party/gender composition on } \\
\text { 1 January } 2018\end{array}$} & \multicolumn{2}{|c|}{ Seats in Cabinet } & \multicolumn{2}{|c|}{$\begin{array}{l}\text { Seats held by } \\
\text { women }\end{array}$} & \multicolumn{2}{|c|}{ Seats in Parliament } \\
\hline & & $N$ & $\%$ & $N$ & $\%$ of party & $N$ & $\%$ \\
\hline & $\begin{array}{l}\text { Fidesz-Hungarian Civic Union } \\
\text { (Fidesz) }\end{array}$ & 6 & $46.2 \%$ & 0 & $0 \%$ & 114 & $57.3 \%$ \\
\hline & $\begin{array}{l}\text { Christian-Democratic People's } \\
\text { Party (KDNP) }\end{array}$ & 4 & $30.7 \%$ & 0 & $0 \%$ & 17 & $8.5 \%$ \\
\hline & No party affiliation & 3 & $23.1 \%$ & 0 & $0 \%$ & 0 & $0 \%$ \\
\hline & Totals & 13 & $100 \%$ & 0 & $0 \%$ & 131 & $65.8 \%$ \\
\hline
\end{tabular}

B. Composition of Orbán IV Cabinet on 18 May 2018

Ministerial title

Minister

Prime Minister

Deputy Prime Minister for Hungarian

Viktor Orbán (1963, male, Fidesz)

Communities

Deputy Prime Minister, Minister of Finance

Deputy Prime Minister, Minister of Interior

Head of the Cabinet of the Prime Minister

Minister of the Prime Minister's Office

Minister of Human Capacities

Minister of Agriculture

Minister for Innovation and Technology

(Innovációs és Technológiai Minisztérium)

Minister of Justice

Minister of Foreign Affairs and Trade

Minister of Defense

Minister without Portfolio

Zsolt Semjén (1962, male, KDNP)

Mihály Varga (1965, male, Fidesz)

Sándor Pintér (1968, male Fidesz)

Antal Rogán (1972, male, Fidesz)

Gergely Gulyás (1981, male, Fidesz)

Miklós Kásler (1950, male, non-partisan)

István Nagy (1967, male, Fidesz)

László Palkovics (1965, male, non-partisan)

László Trocsányi (1956, male, non-partisan)

Péter Szijjártó (1978, male, Fidesz)

Tibor Benkő (1955, male, non-partisan)

János Süli (1956, male, KDNP)

Minister without Portfolio

Andrea Bárfai-Mager (no data, female, non-partisan)

C. Changes in composition of Orbán IV Cabinet during 2018

Ministerial title Outgoing minister Outgoing date Incoming minister Comments

None

D. Party/gender composition Seats in Cabinet Seats held by Seats in Parliament on 31 December 2018 women

$\begin{array}{lllll}N & \text { \% } & \text { \% of party } \quad N & \%\end{array}$

No change after 18 May 2018

Note: ${ }^{a}$ Between 6 and 18 May, the government functioned as a caretaker government.

Source: Hungarian government, 2018 (www.kormany.hu). 
Table 4. Party and gender composition Parliament (Magyar Országgyúlés) in Hungary in 2018

\begin{tabular}{|c|c|c|c|c|c|c|c|c|c|c|c|c|}
\hline \multirow[b]{3}{*}{ Party } & \multicolumn{4}{|c|}{1 January 2018} & \multicolumn{4}{|c|}{ April 2018, elections } & \multicolumn{4}{|c|}{31 December 2018} \\
\hline & \multicolumn{2}{|r|}{ All } & \multicolumn{2}{|c|}{ Women } & \multicolumn{2}{|c|}{ All } & \multicolumn{2}{|c|}{ Women } & \multicolumn{2}{|c|}{ All } & \multicolumn{2}{|c|}{ Women } \\
\hline & $N$ & $\%$ & $N$ & $\%$ & $N$ & $\%$ & $N$ & $\%$ & $N$ & $\%$ & $N$ & $\%$ \\
\hline $\begin{array}{l}\text { Fidesz-Hungarian Civic } \\
\text { Union (Fidesz) }\end{array}$ & 114 & $57.3 \%$ & 8 & $7.0 \%$ & 117 & $58.8 \%$ & 10 & $8.5 \%$ & 116 & $58.6 \%$ & 10 & $8.6 \%$ \\
\hline $\begin{array}{l}\text { Movement for a Better } \\
\text { Hungary (Jobbik) }\end{array}$ & 24 & $12.1 \%$ & 2 & $8.3 \%$ & 26 & $13.1 \%$ & 3 & $11.5 \%$ & 21 & $10.6 \%$ & 2 & $9.5 \%$ \\
\hline $\begin{array}{l}\text { Christian-Democratic } \\
\text { People's Party (KDNP) }\end{array}$ & 17 & $8.5 \%$ & 1 & $5.9 \%$ & 16 & $8.0 \%$ & 1 & $6.2 \%$ & $16^{\mathrm{a}}$ & $8.1 \%$ & 1 & $6.25 \%$ \\
\hline $\begin{array}{l}\text { Hungarian Socialist } \\
\text { Party/Magyar Szocialista } \\
\text { Párt (MSZP) }\end{array}$ & 28 & $14.1 \%$ & 3 & $10.7 \%$ & 15 & $7.6 \%$ & 3 & $0.2 \%$ & 15 & $7.6 \%$ & 3 & $0.2 \%$ \\
\hline $\begin{array}{l}\text { Politics Can Be Different } \\
\text { (LMP) }\end{array}$ & 6 & $3 \%$ & 3 & $50 \%$ & $10^{\mathrm{b}}$ & $4.5 \%$ & 3 & $0.3 \%$ & 6 & $3.1 \%$ & 2 & $33.3 \%$ \\
\hline Democratic Coalition (DK) & 0 & $0 \%$ & 0 & $0 \%$ & 9 & $4.5 \%$ & 1 & $11.1 \%$ & 9 & $4.5 \%$ & 1 & $11.1 \%$ \\
\hline $\begin{array}{l}\text { Dialogue for } \\
\text { Hungary/Párbeszéd } \\
\text { Magyarországért (PM) }\end{array}$ & 0 & $0 \%$ & 0 & $0 \%$ & 5 & $2.5 \%$ & 2 & $0.45 \%$ & 5 & $2.5 \%$ & 1 & $0.2 \%$ \\
\hline Member from nationality list & 0 & $0 \%$ & 0 & $0 \%$ & 1 & $0.5 \%$ & 0 & $0 \%$ & 1 & $0.5 \%$ & 0 & $0 \%$ \\
\hline Independents $^{\mathrm{a}}$ & 10 & $5.0 \%$ & 3 & $30 \%$ & 1 & $0.5 \%$ & 0 & $0 \%$ & 9 & $4.5 \%$ & 3 & $3.33 \%$ \\
\hline Totals & 199 & $100 \%$ & 20 & $10 \%$ & 199 & $100 \%$ & 23 & $11.6 \%$ & 198 & 100 & 23 & $11.6 \%$ \\
\hline
\end{tabular}

Notes: ${ }^{\text {a }}$ One MP of Fidesz (Ferenc Hirt) deceased in December 2018 and his place was only taken by a KDNP MP (István Hollik) in February 2019. Thus, the total number of MPs was 198 on 31 December 2018. ${ }^{b}$ Szabolcs Szabó, who won a mandate as a candidate of Együtt, joined the PPG of LMP upon entering Parliament.

Source: Hungarian Parliament, 2018 (www.parlament.hu).

\section{Political party report}

The opposition parties faced many external and internal challenges throughout the year. At the beginning of 2018, the State Audit Office imposed fines on several opposition parties for accepting illegal party financing. Although the payment deadline was postponed to a post-election date, it put further pressure on parties to run the maximum number of candidates in order to access campaign funds. After the election, smaller opposition parties such as the Together-Party for a New Era/Együttt-a Korszakváltók Pártja (Együtt) collapsed under the financial pressure, and while some started crowdfunding initiatives to be able to cover their expenses, it became clear that only parliamentary parties could sustain their activities.

The issue of the strategic withdrawal of candidates in SMDs affected opposition parties well beyond the election date. In April, the ethical committee of Politics Can Be Different/Lehet Más a Politika (LMP) launched a series of investigations against the party leaders' decision to withdraw candidates based on the claim that the action was opposed to the party's official stance. As a result, Ákos Hadházy, who stepped back from his copresident post right after the election, and Bernadett Szél, co-president of the party at the time, were barred from holding party positions. With several other members affected, the 
Table 5. Changes in political parties in Hungary in 2018

A. Party institutional changes in 2018

Movement for a Better Hungary (Jobbik) split after László Torockai, Mayor of Ásotthalom, was banned from the party on 6 June, followed by several founding members who later decided to found a new party (see below)

Our Homeland Movement/A Mi Hazánk Mozgalom was founded on 20 August

B. Party leadership changes in 2018

LMP, party co-president Ákos Hadházy (1974, male, LMP) resigned after the defeat at the parliamentary elections; replaced by László Keresztes (1975, male, LMP) on 25 May

LMP, party co-president Bernadett Szél (1977, female, LMP) resigned from the presidency on 21 August; replaced by Márta Demeter (1983, female, LMP) on 20 October

Jobbik party president Gábor Vona (1978, male, Jobbik) resigned after losing the parliamentary elections on 9 April; replaced by Tamás Sneider (1972, male, Jobbik)

Our Homeland Movement party president László Torockai (1978, male, Our Homeland Movement) became founding president of the new party Our Homeland Movement on 23 June

MSZP party president Gyula Molnár (1961, male, MSZP) resigned after the defeat at the parliamentary elections; replaced by Bertalan Tóth (1975, male, MSZP) on 17 June

Source: Hungarian News Agency (MTI), 2018 (www.mti.hu).

disintegration of the party became apparent and several MPs quit the LMP's parliamentary party group, while Tamás Meszerics, Member of the European Parliament, also withdrew from the party.

The biggest opposition party, Jobbik, which received the highest fine of roughly $€ 360,000$, also faced crucial internal debates after Gábor Vona, leader of the party, resigned. Conflicts about the party's ideological shift towards the centre-right and political strategy regarding cooperation with other opposition parties resurfaced and split the party base and its leadership.

After the election of the new party leader, Tamás Sneider, his challenger, László Torockai, established a new organization after leaving Jobbik followed by other prominent party members resulting in the split of the party's parliamentary party group. Under the leadership of Torockai, who is the Major of Ásotthalom and famous for the organization of a local paramilitary organization (Betyársereg), a new political movement called Our Homeland Movement/A Mi Hazánk Mozgalom was founded on 20 August, aiming at returning to the original radical political roots.

After the electoral defeat, the Hungarian Socialist Party/Magyar Szocialista Párt (MSZP) saw a leadership change as well, since Gyula Molnár and the entire party board resigned. After a highly contested election between former party leader Attila Mesterházy and the parliamentary party group leader, Bertalan Tóth, Tóth emerged as the winner.

\section{Institutional change report}

The most significant institutional change occurred in June when the seventh amendment of the Hungarian Basic Law was passed, paving the way for further institutional changes 
such as the set-up of a two-level administrative court system with courts addressing firstinstance cases and an Administrative Supreme Court having the same status as the Curia, the highest judicial authority in Hungary, which examines appeals submitted against the decisions of the regional courts and reviews final decisions in case they are challenged through an extraordinary remedy. The administrative courts that will start running in 2020 will be ruling in cases concerning administrative regulations by Hungarian authorities such as taxes, construction permits and the disclosure of public interest data. The new system has been highly criticized owing to its dependence on the Minister of Justice who will be in charge of appointing the judges of the new court. The amendment of the Basic Law included other highly controversial legislation regarding the living condition of the homeless who were banned from sleeping in the streets, resulting in the criminalization of homelessness, and provisions regarding immigration stating that 'no alien population shall be settled in Hungary?

The amendment was closely related to the government-sponsored legislative package consisting of three bills called 'Stop Soros' which was designed allegedly to fight organizations supporting illegal immigration. Based on the new regulation, organizations supported from abroad must register and account for their activities and pay special immigration financing duties on benefits originating from abroad. The package also includes the establishment of a new crime category consisting of supporting and promoting illegal immigration.

While not strictly of a legal nature, the reshaping of the Hungarian media landscape was a game-changer in many ways in Hungary. After the fallout with Orbán in 2017, the fate of Lajos Simicska's right-wing media conglomerate, including a television station, print and online media outlets and radio channels, was financially and political unstable. While some items such as the right-wing newspapers Magyar Nemzet and Heti Válasz. were suspended, others such as the news channel Hír TV were taken over by progovernment owners after the election. In order to manage the diverse media portfolio efficiently and securely, a new conglomerate was established in November 2018 when the oligarch Lórincz Mészáros donated his media company shares to the Central European Press and Media Foundation. The foundation soon acquired the ownership of several other media outlets including notorious right-wing publications such as Figyelö, the daily circulated free local newspaper Lokál and the most read online news website Origo. While the move seems a business transaction, nevertheless the merger allows the foundation to control almost 500 media outlets and reach out to the vast majority of Hungarian voters.

\section{Issues in national politics}

After the election, the Fidesz-KDNP government was keen to keep immigration on the agenda. While the negative campaign's flagship was the Stop Soros package discussed above, a more positive, solution-based approach was also needed. Subsequently, one of Fidesz's most prominent policies, its generous system of family-friendly state subsidies, became reframed as an alternative solution to the European demographic problem. Following up on earlier similar endeavours, the National Consultation on Families was 
launched in November with the first question being: 'Do you agree that the population decline should be tackled not by immigration but by stronger support for families?' Based on the results, the government promised to implement a system with further increased subsidies designed to boost Hungarian demographics in the long-run. Note that while the system indeed offers generous support to families, most of these policies are dependent upon the families' willingness to raise children and targets middle- to upper-class families.

Another prominent political issue is connected to education and research. The ongoing negotiations between the Central European University (CEU) and the government came to a halt when, upon reaching the self-proclaimed deadline of 1 December without a consensus, the CEU decided to take most of its activities to Vienna. While some of its educational programmes accredited in Hungary stay in Budapest, the Vienna campus would host most of the staff and of many of its in-coming students.

Aside from the CEU, the academic sphere witnessed other major conflicts in 2018. First the government removed gender studies from the list of approved master's programmes in the summer of 2018, resulting in protest mainly from Hungarian and international academic circles. A more visible conflict erupted when a new legislative draft was presented shifting half of the Hungarian Academy of Science's (MTA) budget to the Ministry of Innovation and Technology. The proposed restructuring endangered the financial stability and academic autonomy of the MTA and its network of research institutions, thus the academy resisted and engaged in an ongoing debate about proposed reforms. The academy agreed to audit its research network and presented a strategic proposal for the revision, but it demanded autonomous access to its budget (HAS, 2018). The debate did not reach a conclusion, with a decision expected in the first half of 2019.

While both the CEU and the MTA conflicts prompted civil protest, it was the amendment to the Labour Law raising the limit of yearly overtime that received the most public attention in 2018. The parliamentary process of the bill was already out of the ordinary as opposition MPs tried for obstruction through the introduction of a series of amendments, then physically blocked the Speaker's podium to prevent voting, and used billboards, sirens and whistles to interrupt the session. After the bill was passed, the opposition continued its protest outside Parliament, culminating in a series of civil demonstrations against the socalled 'Slave Law'. According to analysts, the events were extraordinary as they prompted an unexpected unity among opposition MPs and enabled them to formulate a message that resonated with the public (Policy Solutions 2019).

Hungarian political developments triggered international attention from various organizations (such as the Venice Commission and the Hungarian Helsinki Committee) as well as the European Parliament, which voted to initiate the Article 7 procedure against Hungary in September. The resulting Sargentini report was highly critical of the Orbán government, citing restriction of the press and threats to the independence of the judiciary, among other claims. While the government rejected most of the allegations and refused to implement the proposed changes, Orbán pointed out that the question of immigration induces rupture in the European People's Party and criticized the party for taking sides with the Socialists and Liberals on this issue. With the upcoming European parliamentary elections, these conflicts in the European political arena are expected to gain further momentum in 2019. 


\section{Sources}

HAS. (2018). An Immediate Agreement and Clear Policy is Demanded from ITM by MTA. Available online at: https://mta.hu/english/an-immediate-agreement-and-clear-policy-is-demanded-from-itm-by-mta109225, last accessed 10 March 2019.

ODHIR. (2018). Hungary, parliamentary Elections, ODIHR Limited Election Observation Mission Final Report. Available online at: https://www.osce.org/odihr/elections/hungary/385959?download=true, last accessed 10 March 2019.

Policy Solutions. (2019). Hungarian Politics in 2018. Available online at: https://www.policysolutions.hu/ userfiles/Hungarian_Politics_in_2018_web.pdf, last accessed 10 March 2019. 